\title{
Factors Influencing Taxpayers' Willingness to Pay Tax: A study of SMEs in Klang Valley
}

\author{
Jing-Nie $\mathrm{Ng}^{1}$, Teck-Heang Lee ${ }^{2}$, Siew-Chin Wong ${ }^{3}$ \\ ${ }^{1,2,3}$ Faculty of Business, Economics and Accounting, HELP University, Malaysia, \\ E-mail: lee.teck.heang@help.edu.my (Corresponding author)
}

\begin{abstract}
Tax revenue is an important source of income for the government and it provides the necessary funds to finance various government expenditure. The study aims to identify the factors that will influence taxpayers' willingness to pay tax. One hundred SMEs business owners from Klang Valley participated in the questionnaire survey. SmartPLS3.2.9 was used to analyse the responses gathered. The study found that only perceived government spending affects the SMEs business owners' willingness to pay tax. Hence, to improve tax revenue for the country, the government should be more cautious in making government expenditure. Taxpayers' money should be spent wisely in areas which will bring about both short-term and long-term benefits to the taxpayers.

Key words SMEs, Willingness to Pay Tax, Government Spending, Tax Revenue

Received: 29 Feb $2020 \quad$ (C) The Authors 2020

Revised: 10 Mar 2020 Published by Human Resource Management Academic Research Society (www.hrmars.com)

Accepted: 16 Mar 2020 This article is published under the Creative Commons Attribution (CC BY 4.0) license. Anyone may reproduce, distribute, translate and create derivative works of this article (for both commercial and non-commercial purposes), subject to full attribution to the original publication and authors. The full terms of this license may be seen at: http://creativecommons.org/licences/by/4.0/legalcode
\end{abstract}

\section{Introduction}

Tax revenue is an important source of income for the government and it provides the necessary funds to finance various government expenditure. Despite the importance of the tax revenue to a country, the amount of tax income collected by the government, to a large extend, will depend on the level of taxpayers' willingness to comply with the tax legislations (Deyganto, 2018). Hence, tax compliance is often a challenge for the tax authorities as it is always the taxpayers' intention to maximise their personal wealth through avoidance of tax payment. This is particular true under the present self-assessment system (SAS) which has been implemented since 2001 by the Malaysian tax authorities. Under this system, it allows the taxpayers to compute their tax liability (Isa et al., 2014). According to Palil (2010), one of the major aims of introducing SAS in Malaysia is to collect taxes for the nation at minimum cost. However, the taxpayers who could be the ordinary laymen may not be able to understand the tax laws completely in view of the nature of its complexity. As a result of their ignorance, this may increase the level of non-compliance of the tax laws (Isa et al., 2014; Kamleitner et al., 2012; Darwish, 2014).

The Malaysian government rely very much on the tax revenue collected from the small and medium enterprises (SME) as $98.5 \%$ of the business establishments in the country are SMEs and it contributes $36.6 \%$ of the GDP in 2016 ("Here's Why SME Matters in Malaysia", n.d). To improve and enhance the competitiveness of SMEs, various tax incentives had been implemented over the years by the government. 
It is believed that, by doing so, it promotes a more conducive business environment for SMEs in the country.

The objectives of the present research study are to examine the effects of the following factors on the willingness of the SMEs business owners to pay tax: (i) quality of tax services, (ii) perception of government spending, (iii) ethics and attitude, and (iv) awareness of offences and penalty. The present study will make a contribution as the review of the literature shows that although there are many studies conducted on tax compliance behaviour, there is limited research study on willingness to pay tax in Malaysia. Hence, this study will offer insights into better understanding on the factors that influence taxpayers' willingness to pay tax. In addition, the findings from this study may provide some useful information to the Inland Revenue Board (IRB) and relevant authorities for their future tax policy development and reform.

\section{Literature review and hypotheses development}

\subsection{SMEs and Taxation}

Taxation is a major concern for all businesses sectors as any income derived in any forms through their business operation are subjected to payment of tax. In the case of SMEs in Malaysia, it contributes substantially towards the economic growth of the country. For example, in 2005, there were 518,996 SMEs representing 99.2\% of total establishments in Malaysia ("Status and Performance of Small and Medium Enterprises", 2005) and the number has increased to 907,065 in 2016 ("SME Definitions", 2016) which constitutes $98.5 \%$ of the total establishment in Malaysia. The definition of SMEs of the present study is based on the definition endorsed at the $14^{\text {th }}$ National SME Development Council (NSDC) Meeting in 2013. This definition of SMEs in Malaysia is based on two criteria: (i) Sale turnover and, (ii) the number of fulltime employees (SME Corp. Malaysia, n.d.). The definition of SME for different sectors is shown in Table 1.

Table 1. Definition of SME

\begin{tabular}{|l|c|c|c|}
\hline \multicolumn{1}{|c|}{ Sectors } & Micro & Small & Medium \\
\hline Manufacturing & Sales turnover $<$ & Sales turnover $<$ RM300,000 $<$ & Sales turnover $<$ RM 15 million $<$ \\
& RM300,000 & RM15 millions & RM millions \\
& Or & Or & er \\
& employees $<5$ & employees from 5 to $<75$ & Sales turnover $<$ RM3 millions $<$ \\
Services and other & Sales turnover $<$ & Sales turnover $<$ RM300,000 $<$ & RM 20 millions \\
sectors & RM300,000 & RM3 millions & Or \\
& Or & Or & employees from 5 to $<30$ \\
\hline
\end{tabular}

Source: Adopted from SME Corp. Malaysia (n.d.).

As for income tax, SMEs in Malaysia are required to pay tax under Income Tax Act (ITA)1967. In general, unincorporated businesses are treated as individuals and subjected to progressive tax rate. They are also entitled to claim personal reliefs and rebates. On the other hand, incorporated businesses, either SMEs or large enterprises are treated similarly.

\subsection{Self-Assessment System}

Since 2001, the self-assessment system (SAS) has been implemented in Malaysia for all companies while to other taxpayers in 2004. This implies that there is a significant transfer of responsibility onto taxpayers in terms of their compliance obligation. Under the SAS, taxpayers are required to compute their tax liability. In order to do so, taxpayers must understand and interpret the tax laws that are applicable to them. Furthermore, corporate taxpayers need to observe further tax requirements in SAS. The public ruling of SAS requires all taxpayers to file a correct annual tax return, keep sufficient records and documentations and to observe other tax related requirements (Abdul-Jabbar \& Pope 2008a; Isa et al., 2014).

\subsection{Willingness to pay tax}


Willingness to pay tax refers to compliance of taxpayers to pay tax in accordance with the tax laws. The term tax compliance means complying with the tax reporting requirements, whereby taxpayers file all required tax returns accurately in accordance with the legislations. Non-compliance, on the other hand, means failure to meet tax reporting requirements. It can be intentional or unintentional. Other terms used to describe non-compliance includes tax cheating, evasion and misreporting. Tax evasion means taxpayers have real intention to deliberately mislead or conceal certain tax activities from tax officials. The intention is to pay less tax than is actually owed. Tax evasion takes in the form of understating taxable income or overstating the deductions (Abdul-Jabbar \& Pope, 2008b).

\subsection{Awareness of offences and penalty}

When tax officials conduct audits, some taxpayers may be fined if they have committed any offences. The compliance with tax law is mostly as a result of punishment and of threat of detection (Cherry, 2001). Allingham \& Sandmo (1972) introduced an economic model which indicated that penalties and audit probability have an impact on tax compliance. The higher the penalty and the probability being audited, the higher the compliance level. Hence, tax audit and high penalty rates have deterrent effect to taxpayers. If taxpayers are aware of the consequences of committing offences and penalties, the tendency of evading paying tax will be reduced (Engida \& Baisa, 2014). The findings of Sheikh Obid (2014) concluded that penalty rate has significant effect on encouraging tax compliance.

Hypothesis 1: Awareness of penalty rate has a significant positive relationship with the willingness to pay tax.

\subsection{Ethics and attitude}

Taxpayers' ethics and attitude towards payment of tax can be influenced by psychological factors. Theory of Reasoned Action and Theory of Planned Behaviour are used to identify taxpayers' behaviour based on their intention. These models made an assumption that ethics encourage individual to act in certain way. For instance, a negative attitude of taxpayers tends to be less willing to pay tax (Palil, 2010). Similarly, Jackson and Milliron (1986) found that attitudes towards taxation have an influence towards taxpayers' willingness to pay tax. Saad (2014) conducted an interview to find out the reasons for tax noncompliance. He found out that taxpayers' greediness and belief that they can avoid paying tax motivate them to constantly not to comply with their tax obligations.

Hypothesis 2: Ethics and Attitude have a significant positive relationship with the willingness to pay $\operatorname{tax}$

\subsection{Perception of government spending}

When taxpayers pay their taxes, they are sensitive to what and how the government will spend their tax money. Taxpayers usually expect that the tax collected will be used in a rational, equitable and economical manner by the government. This is common especially those who pay high amounts of taxes. It is reasonable to assume that taxpayers will be less willing to pay tax if they believe the government did not spend the tax revenue wisely. The perception of taxpayers has potential importance in determining taxpayers' compliance behaviour. For example, if the government spent the tax revenue wisely on basic utilities such as healthcare, education, and infrastructure, it is most likely that the voluntary compliance to be increased (Engida and Baisa, 2014). On the contrary, if tax revenue is spent unwisely, taxpayers may feel betrayed and attempt to evade. According to Helhel \& Ahmed (2014), when public trusts the government, the tendency of declaring the correct amount of taxable income will be increased.

The government should spend the tax revenue collected wisely as the taxpayers' perceptions are important in determining their compliance (Palil, 2010). This is also supported by Zhang et al. (2016) where they conducted a research in the United Kingdom and Italy. This study indicated that citizens are more likely to pay their taxes if they have faith in the government and the tax revenue collected will be spent wisely. Their study revealed the wide differences in level of tax compliance across the European Union. In Italy, the Italians are more likely to evade tax as they believe that the government is also cheating them by 
inefficiently using the tax revenue. On the contrary, the Northern Europeans are more willing to pay taxes because the taxes they paid is reflected on the public service they personally used and valued.

Hypothesis 3: Perception of government spending has a significant positive relationship with the willingness to pay tax.

\subsubsection{Quality of Tax Service}

Quality of service is a comprehensive process where customers evaluate a particular service and to what extent it satisfices their expectations (Al-jazzazi \& Sultan, 2017). An organization cannot survive if it does not meet the expectations or exceed the customers' satisfaction. This idea is also supported by Asubonteng et al. (1996). They asserted that service quality is measured by taking the difference between the expected services to be received and the perceptions of the services they received. Customers will evaluate the service quality as low if the performance does not meet the expectation and vice versa.

Taxpayers should be treated in a similar way as how private sectors treat their customers. This is because positive perception of taxpayers towards tax service quality will lead to higher tax compliance (Ali Al-Ttaffi \& Abdul-Jabbar, 2016). In the United States, the satisfaction towards the tax authority was low as the quality of service by the Inland Revenue Service is worsened. Tax authority can improve the compliance of taxpayers if they cooperate with taxpayers by treating taxpayers as their partners (Torgler, 2007). Muhammad \& Saad (2016) also agreed that the quality of services provided is one of the crucial factors for tax compliance. In the study of Ali Al-Ttaffi \& Abdul-Jabbar (2016), they conducted a study on the perceived quality of service in Yemen. The outcome from this study indicated that taxpayers in Yemen perceived quality of service as low. This perception is probably the result from the low accountability level from the government agencies where they did not meet the expectations of the taxpayers. Ali Al-Ttaffi \& AbdulJabbar (2016) claimed that there is an inverse relationship between the tax service quality and tax noncompliance behaviour. Tax non-compliance behaviour decreases when tax service quality increases. They also suggested that improve quality of tax services will result in a positive perception and it enhances compliance behaviour.

Hypothesis 4: Good quality of tax services provided has a significant positive relationship with the willingness to pay tax.

\section{Methodology of research}

\subsection{Sample and Demographic profile}

The sampling units were the SMEs businesses registered under IRB. In this study, quota sampling method was applied to determine the respondents as it is based on the proportion of subclasses in the population. This method ensures that primary data collection can be done in shorter time. A total of 100 completed questionnaires were received through a self-administered questionnaire survey. According to SME Corp, the total establishments in Malaysia for the year 2016 is 907,065 and $14.7 \%$ is from Kuala Lumpur and $19.8 \%$ in Selangor. Thus, Klang Valley is selected for this study because it comprises of two regions: WP Kuala Lumpur and Selangor which has the most establishments in Malaysia compared with other states. This current study involved 38 percent of male and 62 percent of female SMEs business owners. Most of the respondents were from the age group $41-50$ years old which constitutes $27 \%$. This is followed by the age group 51- 60 years old which is $24 \%$ of the total respondents. $22 \%$ of the respondents are in the age group of less than 30 years old and $19 \%$ of them are from $31-40$ years old. Lastly, only $8 \%$ of the respondents are from the age group above 60 years old. The highest response rate of this study is respondents with annual business income of less than RM250,000 which constitutes $41 \%$ of the total sample. This is followed by companies with business annual income between RM1,000,000 to RM4,999,999 (23\%) and business income between RM250,000 to RM999,999 (19\%). The remaining respondents are companies with business income between RM5,000,000 to RM9,999,999 and above RM10,000,000 ( $8 \%$ and $9 \%$ respectively). 


\subsection{Convergent Validity}

Data was analysed using SmartPLS3.2.9 as the objective of the study is predicting key target construct and the nature of research is an exploratory in nature (Hair et al., 2017). Table 2 shows the assessment of construct reliability and convergent validity of the constructs of the study. As shown, the composite reliability (CR) values of 0.939 (Awareness), 0.927 (Ethic), 0.951 (Government spending), 0.838 (Quality service) and the dimensions of willingness to pay tax (0.876) indicated that these constructs possess internal consistency (Hair et al., 2017). In addition, current research ensures that there is sufficient convergent validity before data analysis. Convergent validity refers to whether the construct measurement can represent the construct itself. The item of willingness 5 was removed as the factor loading is less than 0.7 (Figure 1). Therefore, they achieve the minimum threshold value of 0.5 for average variance extracted (AVE), which indicated the items loaded to the respective constructs explain more than $50 \%$ of the constructs' variance (Hair et al., 2017).

Table 2. Internal Consistency and Convergent Validity

\begin{tabular}{lcccc}
\hline \multicolumn{1}{c}{ Construct } & Item & Loading & CR & AVE \\
\hline Awareness of Penalty & Awareness 1 & 0.964 & 0.939 & 0.838 \\
& Awareness 2 & 0.926 & & \\
& Awareness 3 & 0.852 & 0.927 & 0.809 \\
Ethic & Ethic1 & 0.946 & & \\
& Ethic2 & 0.962 & 0.951 & 0.853 \\
Perceived Government & Ethic3 & 0.779 & & \\
Spending & GS1 & 0.961 & & \\
& GS2 & 0.878 & 0.866 \\
Quality Service & GS3 & 0.950 & & \\
& QT1 & 0.703 & & \\
& QT2 & 0.675 & & \\
Willingness to Pay Tax & QT3 & 0.710 & & \\
& QT4 & 0.903 & & \\
& Willingness1 & 0.832 & & \\
& Willingness2 & 0.817 & & \\
& Willingness3 & 0.831 & & \\
& Willingness4 & 0.712 & & \\
\hline
\end{tabular}

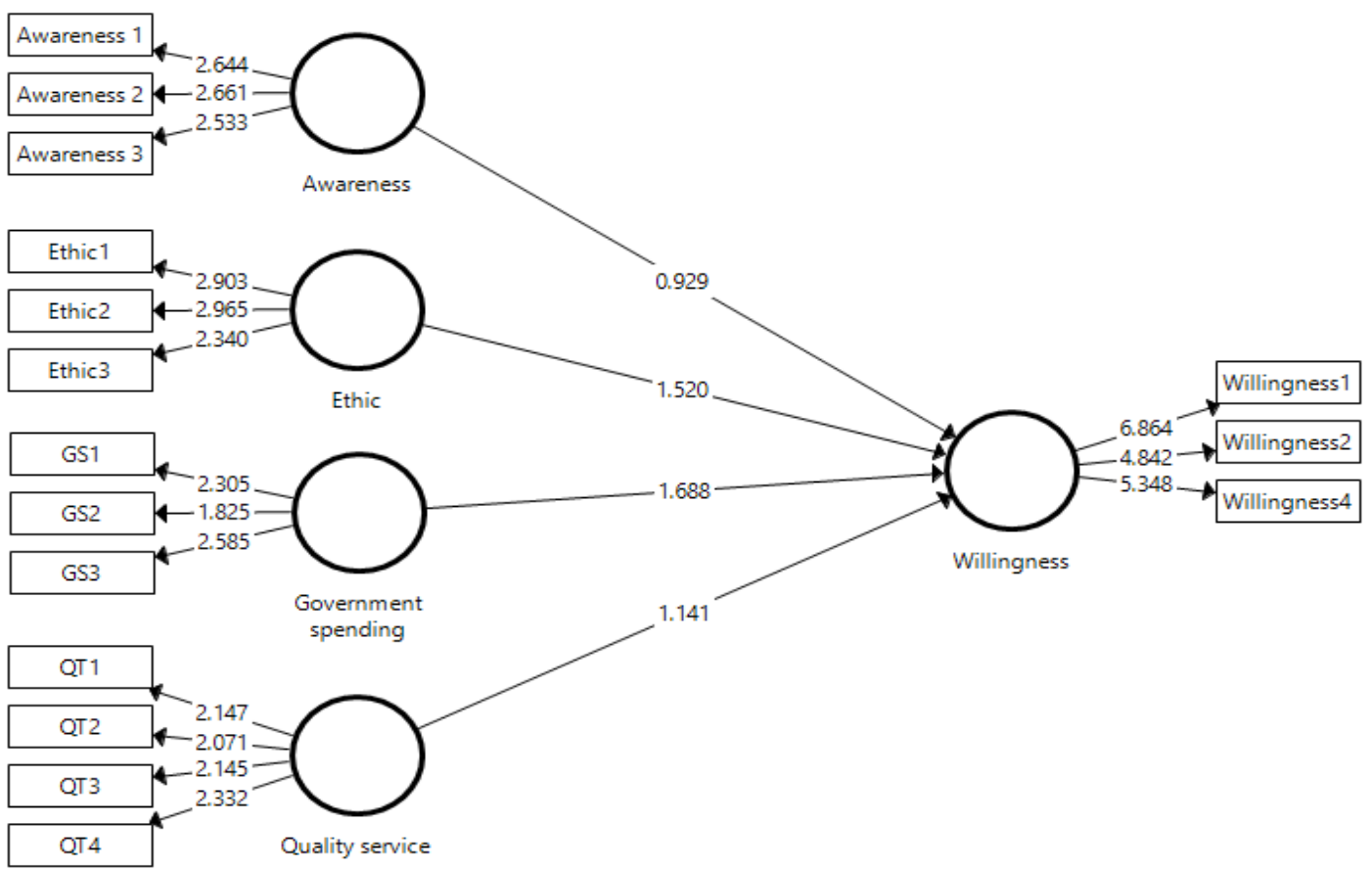

Figure 1. Structural model 


\subsection{Discriminant Validity}

Discriminant validity refers to the degree to which indicators differentiate across constructs or measure distinct concepts by examining the correlations between the measures of potential overlapping (Ramayah et al., 2018). Based on Fornell and Lacker's (1981) criterion as shown in Table 3, a latent variable should explain better the variance on its own indicators than the variance of the latent variables. The correlations for each construct were less than the square root of AVE for the indicators measuring that particular construct, which indicates adequate discriminant validity. The alternative approach to assess discriminant validity is through Heterotrait-Monotrait (HTMT) ratio correlations. HTMT refers to the ratio of correlations within the constructs to correlations between the constructs (Ramayah et al., 2018). All Heterotrait-Monotrait (HTMT) of correlation values for current study are clearly lower than the more conservative value of 0.85 (Kline, 2011). As can be seen in Table 4, neither of the confidence intervals includes the value 1 . The bootstrap confidence interval results of HTMT criteria clearly indicated the measurement model demonstrates adequate discriminant validity in this study (Hair et al., 2017).

Table 3. Discriminant Validity (Fornell and Larcker)

\begin{tabular}{lccccc}
\hline & Awareness & Ethic & Government spending & Quality service & Willingness \\
\hline Awareness & 0.915 & & & & \\
Ethic & 0.238 & 0.900 & & & \\
Government spending & 0.212 & 0.451 & 0.931 & & \\
Quality service & 0.124 & 0.45 & 0.321 & 0.753 & \\
Willingness & 0.122 & -0.169 & 0.108 & -0.183 & 0.799 \\
\hline
\end{tabular}

Note: Diagonals represent the square root of the AVE, while the off-diagonals represent the correlations

Table 4. Heterotrait-Monotrait Ratio (HTMT)Criterion

\begin{tabular}{|c|c|c|c|c|c|}
\hline & Awareness & Ethic & $\begin{array}{l}\text { Government } \\
\text { spending }\end{array}$ & Quality service & Willingness \\
\hline \multicolumn{6}{|l|}{ Awareness } \\
\hline Ethic & $\begin{array}{c}0.256 \\
\text { Cl.85 (0.093, } \\
0.425) \\
\end{array}$ & & & & \\
\hline $\begin{array}{l}\text { Government } \\
\text { spending }\end{array}$ & $\begin{array}{c}0.179 \\
\text { Cl.85 (0.077, } \\
0.358)\end{array}$ & $\begin{array}{c}0.543 \\
\text { Cl.85 (0.371, } \\
0.702)\end{array}$ & & & \\
\hline Quality service & $\begin{array}{c}0.153 \\
\text { Cl.85 (0.104, } \\
0.376) \\
\end{array}$ & $\begin{array}{c}0.372 \\
\text { Cl.85 (0.214, } \\
0.564) \\
\end{array}$ & $\begin{array}{c}0.274 \\
\mathrm{Cl} .85(0.169,0.478)\end{array}$ & & \\
\hline Willingness & $\begin{array}{c}0.141 \\
\text { Cl.85 (0.113, } \\
0.316)\end{array}$ & $\begin{array}{c}0.173 \\
\text { Cl.85 (0.116, } \\
0.350)\end{array}$ & $\begin{array}{c}0.145 \\
\mathrm{Cl} .85(0.081,0.327)\end{array}$ & $\begin{array}{c}0.133 \\
\text { Cl.85 (0.111, } \\
0.341)\end{array}$ & \\
\hline
\end{tabular}

\section{Findings}

\subsection{Assessment of Structural Model}

The path analysis in Table 5 revealed that perceived government spending factors was found to have a positive impact on willingness to pay tax among the respondents. Specifically, perceived government spending $(\beta=0.238)$, $t$-value $(1.800>1.645)$ have a significant positive influence on willingness to pay tax at $95 \%$ confidence level. Thus, H3 was accepted. The study found that $11.5 \%$ of willingness to pay variance can be explained by perceived government spending factors. In contrast, the findings found that the awareness of penalties and offences of not complying tax laws, t-value $(0.887<1.645)$; ethical belief and positive attitudes $(\beta=-0.234)$, t-value $(1.580<1.645)$, and quality of tax services provided by tax authority $t-$ value $(0.759<1.645)$ factors are not positively correlated to willingness to pay tax. Therefore, H1, H2 and H4 were rejected. 
Next, the effect sizes $\left(f^{2}\right)$ are assessed. Hair et al. (2017) suggests the examining of the $\mathrm{R}^{2}$ changes by evaluating whether the omitted exogenous construct has a substantive impact on the endogenous construct. Table 3 shows the $f^{2}$ value of perceived government spending is 0.049 . The results show that the variable has small effect in producing the $R^{2}$ for willingness to pay tax. Predictive relevance $\left(Q^{2}\right)$ is then evaluated to study the predictive power of exogenous constructs over endogenous constructs. $A Q^{2}$ value greater than 0 means that the exogenous constructs have the predictive capability on the endogenous constructs (Hair et al., 2017). In this study, the $Q^{2}$ value of willing to pay tax (0.49), greater than 0 , indicates that the model has sufficient predictive relevance.

Table 5. Summary of Structural Model

\begin{tabular}{|c|c|c|c|c|c|c|c|c|}
\hline Hypothesis & Relationships & $\begin{array}{l}\text { Std } \\
\text { Beta }\end{array}$ & $\begin{array}{l}\text { Std. } \\
\text { Error }\end{array}$ & t-value & Decision & $\mathbf{R}^{2}$ & $f^{2}$ & $\mathbf{Q}^{2}$ \\
\hline $\mathrm{H} 1$ & Awareness Willingness to pay tax $\longrightarrow$ & 0.149 & 0.176 & 0.843 & Rejected & 0.115 & 0.023 & 0.049 \\
\hline $\mathrm{H} 2$ & $\begin{array}{l}\text { Ethical belief and positive attitude } \\
\text { Willing to pay tax } \longrightarrow\end{array}$ & -0.234 & 0.148 & 1.580 & Rejected & & 0.042 & \\
\hline H3 & $\begin{array}{l}\text { Perceived government spending } \\
\text { Willing to pay tax } \longrightarrow\end{array}$ & 0.238 & 0.132 & $1.800 * *$ & Supported & & 0.049 & \\
\hline $\mathrm{H} 4$ & $\begin{array}{l}\text { Quality services provided by tax } \\
\text { authority Willingness to pay tax }\end{array}$ & -0.172 & 0.162 & 1.065 & Rejected & & 0.026 & \\
\hline
\end{tabular}

Note: ${ }^{* *} \mathrm{p}<0.05$

\section{Conclusions}

The research objective of this study is to identify the factors that influence the willingness to pay tax among SMEs business owners in Malaysia. The study found that only perceived government spending affects the SMEs business owners' willingness to pay tax. Hence, to improve tax revenue, the government should be more cautious in making government expenditure. Taxpayers' money should be spent wisely in areas which will benefits the taxpayers such as improving basic facilities that include infrastructures and public services in the country in order to gain taxpayers' confidence and trust.

The study suffers a few limitations. Firstly, this study has collected responses from only 100 SMEs business owners. The reliability of the study can be enhanced if the sample size can be increased. Secondly, the data was collected in Klang Valley only, a wider coverage can be considered by future researchers. Thirdly, the present study adopts a quantitative approach where self-administered questionnaires were used, future researchers may consider to a mixed method approach to include some interviews. It may help to gain a better and more in-depth insight of the current research issues.

\section{References}

1. Abdul-Jabbar, H., \& Pope, J. (2008a). The effect of the self-assessment system on the tax compliance costs of small and medium enterprise in Malaysia. Australian Tax Forum, 23, 291-309.

2. Abdul-Jabbar, H., \& Pope, J. (2008b). Exploring the Relationship between Tax Compliance Costs and Compliance Issues in Malaysia. Journal of Applied Law and Policy, 1 (1), 1-20.

3. Al-jazzazi, A., \& Sultan, P. (2017). Demographic differences in Jordanian bank service quality perceptions. International Journal of Bank Marketing, 35(2), 275-297.

4. Al-Ttaffi, A. L. H., \& Abdul-Jabbar, H. (2016). Service Quality and Income Tax Non-Compliance. Journal of Advanced Research in Business and Management Studies, 4(1), 12-21.

5. Allingham, G. M., \& Sandmo, A. (1972). Income tax evasion: A theoretical analysis. Journal of Public Economics, 1(3-4), 323-338. Retrieved 29 September 2019, from http://www3.nccu.edu.tw/ klueng/tax\%20paper/1.pdf

6. Asubonteng, P., McCleary, K., \& Swan, J. (1996). SERVQUAL revisited: a critical review of service quality. Journal of Services Marketing, 10(6), 62-81.

7. Cherry, T. (2001). "Financial Penalties as an Alternative Criminal Sanction: Evidence from Panel Data". Atlantic Economic Journal, Springer Netherlands, 29(4), 96-114. 
8. Darwish, S. (2014). The Role of Universities in Developing Small and Medium Enterprises (SMEs): Future Challenges for Bahrain. International Business and Management, 8(2), 70-77.

9. Deyganto, K. (2018). Factors Influencing Taxpayers' Voluntary Compliance Attitude with Tax System: Evidence from Gedeo Zone of Southern Ethiopia. Universal Journal of Accounting and Finance, 6(3), pp.92-107.

10. Engida, T., \& Baisa, G. (2014). Factors influencing taxpayers' compliance with the tax system: An empirical study in Mekelle City, Ethiopia. Ejournal of Tax Research, 12(2), 433-452.

11. Fornell, C., \& Larcker, D. (1981). Evaluating structural equation models with unobservable variables and measurement error. Journal of Marketing Research, 18(3), 39-50.

12. Hair, J. F., Hult, G. T. M., Ringle, C. M., \& Sarstedt, M. (2017). A primer on Partial Least Squares Structural Equation modelling (2nd ed.). Thousand Oaks: SAGE Publications.

13. Helhel, Y. \& Ahmed, Y. (2014). Factors Affecting Tax Attitudes and Tax Compliance: A Survey Study in Yemen. European Journal of Business and Management, 6(22), 48-48.

14. "Here's Why SME Matters in Malaysia". Retrieved 23 July 2019, from http://www.smeinfo.com. $\mathrm{my} /$ profile-of-smes.

15. Isa, K., Yussof, S., \& Mohdali, R. (2014). The Role of Tax Agents in Sustaining the Malaysian Tax System. Procedia - Social and Behavioral Sciences, 164, 366-371.

16. Jackson, B., \& Milliron, V. (1986). Tax compliance research: Findings, problems, and prospects. Journal of Accounting Literature, 5, 125-65.

17. Kamleitner, B., Korunka, C., and Kirchler, E. (2012). Tax compliance of small business owners. International Journal of Entrepreneurial Behavior \& Research, 18(3), 330-351.

18. Kline, R. B. (2011). Principles and practice of structural equation modeling (3rd ed.). Guilford publications.

19. Muhammad, S., \& Saad, R. (2016). Determinants of Trust on Zakat Institutions and its Dimensions on Intention to Pay Zakat: A Pilot Study. Journal of Advanced Research In Business And Management Studies, 3(1), 40-46.

20. Palil, M. (2010). Tax knowledge and tax compliance determinants in self-assessment system in Malaysia. Retrieved 29 September 2019, from. https://core.ac.uk/download/pdf/76107.pdf

21. Ramayah, T., Cheah, J., Chuah, F., Ting, H., \& Memon, M. A. (2018). Partial least squares structural equation modeling (PLS-SEM) using SmartPLS 3.0: An updated and practical guide to statistical analysis ( $2^{\text {nd }}$ ed.) Singapore: Pearson

22. Saad, N. (2014). Tax Knowledge, Tax Complexity and Tax Compliance: Taxpayers' View. Procedia - Social And Behavioral Sciences, 109, 1069-1075

23. Obid, S. N. (2004). The Influence of Penalties on Taxpayers' Compliance: A Comparison of the Theoretical Models. IIUM Journal of Economics and Management, 12 (1), 1-30.

24. "SME Definitions". (2016). Retrieved 20 September 2019, from http://www.smecorp.gov.my/ index.php/en/policies/2015-12-21-09-09-49/sme-definition

25. SME Corp. Malaysia (n.d.). Retrieved 30 September 2019, from http://www.smecorp.gov.my/index.php/en/resources/2015-12-21-11-03-46/entrepre-news/162-entreprenews/tahun-2013/328-new-definition-of-smes-an-additional-8-120-establishments-set-to-be-classified-assmes-bringing-the-share-of-smes-to-total-establishments-from-97-3-to-98-5

26. Status and Performance of Small and Medium Enterprises. (2005). Retrieved 20 September 2019, from http://www.bnm.gov.my/files/publication/sme/en/2005/chap_2.pdf

27. Torgler, B. (2007). Tax Compliance and Tax Morale: A Theoretical and Empirical Analysis. Cheltenham, UK.: Edward Elgar Publishing Limited.

28. Zhang, N., Andrighetto, G., Ottone, S., Ponzano, F., \& Steinmo, S. (2016). "Willing to Pay?" Tax Compliance in Britain and Italy: An Experimental Analysis. PLOS ONE, 11(2), 1-14. Retrieved 17 October 2019, from https://journals.plos.org/plosone/article/file?id=10.1371/journal.pone.0150277\&type= printable 